Notre Dame Law School

NDLScholarship

Natural Law Forum

$1-1-1960$

\title{
Natural Natural Law and Positive Natural Law
}

Roscoe Pound

Follow this and additional works at: http://scholarship.law.nd.edu/nd_naturallaw_forum

Part of the Law Commons

\section{Recommended Citation}

Pound, Roscoe, "Natural Natural Law and Positive Natural Law" (1960). Natural Law Forum. Paper 49.

http://scholarship.law.nd.edu/nd_naturallaw_forum/49

This Article is brought to you for free and open access by NDLScholarship. It has been accepted for inclusion in Natural Law Forum by an authorized administrator of NDLScholarship. For more information, please contact lawdr@nd.edu. 


\section{NATURAL NATURAL LAW AND POSITIVE NATURAL LAW*}

Roscoe Pound

LET ME PROPOUND some definitions. Yet I do this with some hesitation. There is no sounder proposition in the lawbooks than the saying of Javolenus: Omnis definitio in jure civili periculosa est. 1 But, as Socrates reminds us, we must seek to be sure what we are talking about.

We could wish that our discourse should proceed from our definitions. But experience seems to show that it is more likely the definitions will grow out of the discourse. What we may be more sure of is the relation of our discourse and of the definition. Our conception of the problem to which our discourse is addressed shapes both. What we are trying to do, why we are trying to do it, and how we are trying to do it, are not wholly separable, and each enters into both definition and discourse.

I distinguish natural natural law and positive natural law, and my proposed definitions are: (1) Natural Natural Law - a rationally conceived picture of justice as an ideal relation among men, of the legal order as a rationally conceived means of promoting and maintaining that relation, and of legal precepts as rationally conceived ideal instruments of making the legal order effective for its ideal end. (2) Positive Natural Law - a system of logically derived universal legal precepts shaped to the experience of the past, postulated as capable of formulation to the exigencies of universal problems and so taken to give legal precepts of universal validity.

The one has given us ideals to which to direct reason as to the legal order, the administration of justice, and the functioning of our apparatus of justice. The other has served to hold us down as we strive to make the positive law in action achieve our ideals of justice in dealing with the controversies of the social and economic order of today. What seems to me the reality behind natural law is that there is an ideal element in law. It is not so much a superior law, much less a superior body of laws or rules of law. It is a vital part of the law itself.

Of those who have professed to expound natural law in recent times I rate highest François Gény. To the Continental jurists of the seventeenth and the eighteenth century, natural law (or perhaps we should say the law of nature)

- This article develops certain of Dean Pound's ideas set out in an earlier article, bearing the same title, which appeared at 68 LaW Quartrely Review 330 (1952).

1. Digest 50.17.202. 
meant an ideal development of precepts of the modern Roman law in which they had been trained and taught to find authoritative principles. Gény saw the importance of technique along with precepts and ideals - put in better order, he considers ideals, precepts, and technique. Under precepts, those which establish principles, starting points for reasoning and rules, attaching definite detailed consequences to definite detailed states of fact, are primary. Precepts defining legal conceptions and precepts establishing standards are secondary. Thus we get an ideal plan of a legal system: a regime of ideals, precepts - principles, rules, conceptions, and standards - and technique, for making effective the ideal of justice. Certainly the technique is not the least of this picture - the process of measuring the precepts and their application by the ideal of what we are trying to do, by what makes for the end of law in action. Gény has given us an idea of the first importance: the idea of measuring of legal precepts - not merely the framing and establishing of them, but their application - by a reasoned technique guided by the ideal of the end of law in action. Here is a lofty program for the jurist. If there were nothing more, the recognition of the role of technique was a great advance.

But is our concern to be simply with the ideal or ideals, or must we be thinking also of experience? Are our ideals derived from reason or are they applications of reason to experience and so shaped much to, and by, experience and so to conditions of time and place? There are broad fields of the law where growth has been confined, and the course of development has seemed to have been fixed by analogies from administration of justice in simple social and economic conditions with resulting inadequacy to the requirements of justice in the complex, crowded social and economic order of today.

Let us look at some of the analogies which have shaped ideals of the law in action today. If you will, they represent experience to which the ideal pictures were drawn and by which they are often to no small extent given shape today.

One of these is the picture of a street fight, and of the legal order as a glorified policing. Historically it goes back to the dramatic ceremony of the legis actio of the period of the strict law in Roman law - the quarrel in which the magistrate says "let go both of you," which legal procedure had not wholly given up as a type of legal proceeding even at the beginning of the present century. A simple fight between neighbors in a rural agricultural society gave an enduring picture for legal procedure.

In the Anglo-American law of reparation for injuries, to which we still give the significant name "Law of Torts," the analogy to which it has de- 
veloped is one of a violent attack by one man upon another with "swords, knives, and staves," an ordinary mode of arguing differences of opinion before the legal order established peace as an everyday condition. Swords, knives, and staves would not go off half cocked, and there was no obvious way in which they could infringe the general security except as instruments of violent attack. Hence the remedy provided by the beginnings of our law was an action of trespass, in which the writ recited an attack with swords, knives, and staves. When the invention of gunpowder made a firearm a threat to the general security even in the hands of one who had no intention of doing harm, the swords, knives, and staves were still used by analogy. The question arose in England in a leading case in 1616.2 The apprentices in the London shops formed trainbands for military drill. In one of the drills there was a sham skirmish in which a musket was accidentally discharged and a participant was wounded. In an action for damages the defendant pleaded that discharge of the musket took place accidentally and by mischance and without any intention to injure. The plaintiff demurred, and the court sustained the demurrer. To bring anything forcibly into contact with the body of another was a "battery" and was actionable unless it could be justified. By the end of the eighteenth century lawyers had found a more inclusive idea to save the analogy. An intentional unjustified attack was a moral fault. So was careless handling of a firearm which subjected another to a risk of injury. The analogy of violent attack could still be used. Simply the action was trespass on the case - on the facts of the particular case which have the effect of an attack.

In 1866 a case $^{3}$ arose where the idea of fault could not be strained to justify recovery; and yet the English courts felt, and an increasing number of courts in a steadily growing number of jurisdictions felt, the loss ought not to fall on the luckless victim of injury. For a long time we have strained to bring recovery within the swords, knives, and staves analogy. Remnants of the old restricted doctrine of liability still embarrass the law of torts.

A like analogy drawn from the simple life of a primitive community is that of nonreturn of a borrowed horse, which has been applied to claims to promised advantages in the commercial operations of the twentieth century.

Endeavor to develop the law of liability so as to treat adequately the condition of personal injury in the operation of mills and factories, railways and bus lines, and aircraft upon the fault theory of the old swords, knives, and staves analogy still hangs on in many old rules awkwardly applied to another economic order.

2. Weaver v. Ward, Hobart 134, 80 Eng. Rep. 284 (K.B. 1616).

3. Rylands v. Fletcher, L.R. 1 Ex. 265 (1866), affd. L.R. 3 H. L. 330 (1868). 
Thinking of liability on the analogy of the street fight still lingers in remnants of the fellow-servant rule, in what is left of contributory negligence, and in resistance to endeavors of courts and legislatures to provide for adequate treatment of the injuries which are unavoidable incidents of industrial undertakings in the complex mechanized economic order of today.

In the last century we sought to broaden the theoretical basis of liability by thinking of liability to repair injury as a corollary of fault. An act of intentional aggression was a moral fault. So also was acting or omitting to act which subjected another to an unreasonable risk of injury resulting in injury. In the search for a more inclusive moral principle, moral blameworthiness was seen to include both intentional aggression and want of care in a course of conduct so as to cause injury. It was even sought to use the idea to explain liability of the head of a household organization. But it could only partially and with much difficulty be made to cover established rules of the common law which imposed liability in an action of trespass on the case for damage by trespassing cattle escaping without fault of the owner, injury by harbored wild animals, and by agents and servants without regard to fault. Liability without fault for acts of servants or agents was reconciled with the fault theory by a fiction of representation. For the rest, these common law liabilities without fault were so palpably irreconcilable with the fault idea of tort that they were often pronounced historical anomalies, and American courts fifty years ago seemed inclined to give them up. Sir Frederick Pollock was convinced that liability without fault was a survival from the primitive household organization of society and was on the way to disappear from the law. Accepting this view, the New York Court of Appeals at first held a Workmen's Compensation Act unconstitutional as an arbitrary and unreasonable imposition of liability, ${ }^{4}$ and a minority of the Supreme Court of the United States took the same position toward some aspects of Workmen's Compensation as late as 1922.5 But with the mechanizing of everything today, the maintaining and employing of instrumentalities of danger to life and limb have been leading to a constantly growing category of liabilities where there has been no real fault. This category is still, largely for procedural reasons, attributed to tort. There is, however, no suggestion of any element of aggression, and in truth the element of wrongdoing is wholly absent. Yet use of terms which connote wrongdoing embarrasses a conspicuously living and growing part of the law. The need here is for more than a rationally conceived idea of ideal universal law. It is for directive thought about the relation of the ideal to the experience which is to be developed by reason.

4. Ives v. South Buffalo Ry. Co., 201 N.Y. 271, 94 N.E. 431 (1911).

5. Arizona Employers' Liability Cases, 250 U. S. 400 (1919); New York Central R.R. v. Bianc, 250 U.S. 596 (1919); Ward \& Gow v. Krinsky, 259 U. S. 503 (1922). 
Enough has been said to show the importance of distinguishing between ideal and analogy. When the legal order is confronted with a new and unprovided for situation, a remedy is found in the analogy of some existing remedy which has proved practicable. The analogy may provide a starting point for reasoning and get the shape of a principle of general law, and in time be elaborated into a proposition of positive natural law. Expectations involved in social life put as ideals may even be made ideals of the expectations of the ideal man in vacuo. In legal history, however, the analogy which served as a starting point colors applications of the principle throughout its history.

There are two functions of natural natural law: (1) creative, to guide us in shaping or formulating legal precepts applicable to new or changing social or economic conditions to which they will be applied or application will be sought in the everyday administration; (2) critical, to provide the basis for intelligent and effective critiques of the received legal precepts of the time and place as to how far they may achieve the end or ends of the legal order when applied to the problems and controversies of the present or the impending future. But is this second function one of a pure natural law? I submit it ought to be.

In its origin natural law was an attempt to replace arbitrary magisterial action by rationally conceived principles or starting points for reasoning in the development of law out of a system of policing. In its development toward fulfillment of the two functions sketched above, it has too often assumed a third function of ingenious and plausible justification of juristic and judicial status quo in a world which does not inevitably stand still.

A philosophical jurisprudence which seeks to give a philosophical account of the body of laws which obtain in the time and place may expound positive natural law - a body of reasoned principles which yield a rational and logically consistent plan of the received legal precepts of the time and place. This finding of a valid legal principle behind legal precepts is a very useful process. But it is easily abused by resorting to it when and where it is not needed, especially where doing this retards operation of the function of keeping legal precepts in touch with the facts of economic activities and relations to which they are to be applied and thus keeping law in touch with life.

Indeed the process has easily turned to one of ingenious justification - not seeking to find how far legal precepts achieve their purpose in application to controversies in the forum, but to show that they are so rationally adapted to ethically considered problems of the legal order that they must of rationally logical necessity be the exact precepts appointed by natural law for controversies within their scope.

To a body of philosophically devised and officially phrased propositions 
of this sort I give the name of positive natural law. Virgil said of the philosopher: "felix qui potuit rerum cognoscere causas." Man has been at the task for centuries. When I remember the questions that were litigated when I came to the bar in 1890 and compare them with those which are discussed by the courts in the week by week advance sheets of the National Reporter System, when I compare how certain we were then that the common law had a settled rule for every case that could be taken to court, and the assurance that the courts had the one right answer at hand if diligence were used to find it, with the way in which what are becoming everyday questions in the courts have to be approached by law student and lawyer and judge today, I can understand the revival of natural law which has marked the first half of the present century.

But an ethical philosophical strait jacket of positive natural law will achieve no more than did the analytical, historical, or the metaphysical strait jackets which have been employed also.

It is not the task of philosophical jurisprudence to prove that we must fit legal precepts and their application necessarily and inevitably to a logically demonstrated pattern of the past. It is rather that we have experience also with which to work in applying given patterns and finding how to shape them to new conditions of fact which confront us. The task of reason is not confined to demonstrating universal and eternal validity of precepts as we find them given us in the legal order.

Natural natural law is too easily thought of as a systematic logical establishing of the validity of positive natural law. Law is not pure reason in vacuo, but reason organizing and developing experience and corrected and developed by further experience.

Natural law has played a great part in legal history. The achievements of natural natural law have been in the theoretical science of law. The achievements of positive natural law have been in replacing the idea of the legal order as policing by one of a system of adjusting relations and ordering conduct by reasoned principles.

An excellent example of positive natural law in action may be seen in the eighteenth-century idea of codification. Natural law was taken to be a body of eternal, exactly defined precepts, applicable to all men, at all times, in all places, under all circumstances. It could be discovered as a complete and logically developed whole by pure reason and reduced to rules of law. The jurist was felt to have a wider task than merely to criticize the received legal precepts of the time and place by the light of the precepts of natural law. He must work out completely in detail all the applications of the eternal ration. ally revealed principles and put them in the form of a code. The code of 
Frederick the Great (1749), the French Civil Code (1804), and the codes in the civil law world (nineteenth century) are the fruits of this idea.

As one reads the pronouncements of the eighteenth-century law-of-nature jurists he cannot but feel how much of what they lay down dogmatically deserves Bentham's gibe, that they expound the authors' personal ideas or those in which he was brought up "as so many branches of the eternal rule of right." 6 But with all allowance for their overconfidence in themselves as repositories of eternal rules of right, as Bentham put it, the assumption that the rules of the civil law, as the civilian knew them, were practical applications of universal ethical or moral principles, was a compelling force in the development of modern law.

Although in an over-all universal rational view of conduct and relations of men the local and temporary are of little significance, the administration of justice has to deal with them. They must be provided for in the law in action, however little weight they carry in the science of law in the books. What happened through the violent activity of some aggressive individual in village $A$ was of little concern unless as a bad example in village $B$, and was of no concern in village $C$ one hundred miles away. Today what happens anywhere in the world may very often have social or economic or political effect over a wide area. The analogy of policing the small town in a rural, agricultural economy, which was once the basis of juristic reasoning, is no longer applicable. It is often downright harmful. But most of our mode of thought about principles and the basis of legal institutions was shaped by the small-town analogy.

An idea of law as an aggregate of laws and of a law as a command of the local political sovereign, goes on the policing concept of the legal order. Morals and law are taken to be systems of universal policing. But when you put it in this way it must be borne in mind that we are no longer policing small towns but large parts of a world - if not a whole world - which has gone far beyond a small-town agricultural economy.

Judge Story's idea of a general commercial law, applicable to commercial transactions such as bills and notes everywhere, led to the famous decision in Swift v. Tyson, ${ }^{7}$ which embarrassed the relations of state and federal courts for substantially a century. His view might be compared to Jitta's saying that a sale is a sale, whether in New York or in Amsterdam. Here we have a general idea of universal legal transactions. Story seems to have thought of negotiability of a promissory note as an institution of natural law. He says:

The law respecting negotiable instruments may be truly declared in the

6. Bentham, Thir Theory of Leoislation 7 (Ogden ed., 1931).

7. 41 U.S. (16 Pet.) 1 (1842). 
language of Cicero, adopted by Lord Mansfield . . to be in a great measure, not the law of a single country only, but of the commercial world. Non erit alia lex Romae, alia Athenis, alia nunc, alia posthac, sed et apud omnes gentes, et omni tempore, una eademque lex obtinebit. ${ }^{8}$

While the Supreme Court of the United States was laying this down, the legislature of Illinois was making a promissory note payable in farm produce negotiable. Was that "contrary to common right and reason"?

Should we distinguish? Should we say: Natural law has to do with moral obligation, but the exact limits of negotiability are a matter of the understanding of those engaged in commerce and are to be governed by the moral obligation arising from those limitations, not by a moral principle inherent in the idea of a promissory note as a legal transaction? As to this, compare a group of questions as to use and pollution of the water of a running stream which have given the courts much trouble. In a case ${ }^{10}$ in Rhode Island there was a stream on one side of a road and a farm through which the stream ran. The farmer used the stream to water his stock and had a well which supplied water for domestic purposes. On the other side of the road an oil refinery was built. It was built with all care; nothing that could be done to avoid injury to anyone from waste products of the refining process was omitted. Tall smokestacks carried the waste products to the upper air, where they were dissipated by the wind and did no damage. But at times there would happen what meteorologists call an inversion. A low-lying layer of cold air prevented the waste products from going up the smokestack and being dissipated. They settled down to the ground, were washed by rains into the soil, poisoned the percolating water and so the well and the brook, killed the farmer's pigs and poultry, and made his well useless. The court considered that on a universal principle of justice there could be no liability where there was no fault, and denied recovery.

In a case ${ }^{11}$ in Kansas there was pollution of the water of a running stream by discharge of oil from a refinery near plaintiff's dairy farm. So far as appeared the plaintiff was the only person damaged. But the court considered that pollution of the water of a running stream was a nuisance and ground of action. In each case the court goes on a reasoned universal fundamental principle: in the first, that the act of pollution of the water of the running stream could create liability only if done in a way involving moral fault; in the second, that the pollution of the water of a running stream of itself cre-

8. Id. at 18 .

9. See Bilderback v. Burlingame, 27 Ill. 337 (1862); Stewart v. Smith, 28 Ill. 397 (1862).

10. Rose v. Socony-Vacuum Corp., 54 R. I. 411, 173 Atl. 627 (1934).

11. Helms v. Eastern Kansas Oil Co., 102 Kan. 164, 169 P. 208, L.R.A. 1918 C 227 (1917). 
ated liability - it cut off use of a natural resource of society, even if only for one man.

Was there something operating behind the rational scene in these cases which does not appear in the reports? Is it significant that Rhode Island is primarily industrial whereas Kansas is primarily agricultural? In the one state agriculture plays little part in the economy; in the other, until recently at least, industry was almost negligible in the economy. It would seem as wrong in the one state to impose a burden upon industry for the benefit of a relatively negligible agriculture as it would be in the other to put a burden upon agriculture for the benefit of a then substantially negligible industry. This may be thinking below the plane of eternal verities. But to think upon that plane calls for a superordinary ethical, economic, and philosophical equipment. Is it after all a question of abstract universal reasoning or merely one of economics which may well get different answers in Rhode Island and Kansas?

Turn to a related difficult and controverted question, the question of strict or absolute liability, so called, in comparison with fault liability which was held in classical common law thinking to stand upon an unchallengeable moral basis. What is the moral basis of what is called "spreading the loss"? The most effective economic method of repairing injuries inevitable in the everyday activities of our time is to put the burden of repairing the loss upon the activity as part of the cost of production. This rational solution in view of the whole economic situation might be called natural, using the term "natural" to mean a principle found by a process of reason applied to solution of a practical problem to give a practically workable result. But this does not start with the principle that is finally applied. When we start with the principle, we usually start in reality from the analogy of rules worked out in the past to meet situations that no longer obtain.

Reason and reasoning are not necessarily and exactly the same thing. To construct a pattern, shaped by analogies which served for social and economic conditions of the past, behind legal precepts to justify applying these precepts to wholly different societies or conditions of today is reasoning, but it does not demonstrate that these precepts are forever applicable as demonstrated reason. Measured by even the metaphysical theory of the end of law, they are not forever applicable as demonstrated reason. Measured by even that theory, when results are helpful in.relation to problems of administration of law today. they do not come to the measure of what is postulated for natural law.

An example of positive natural law in action may be seen in the persistence of the ethical theory of moral fault as the basis of liability to repair injuries inevitably incidental (as experience has thus far shown) 
in the operation of great industrial enterprises. Fault of those in control of the enterprise or fault of those injured may exist in single cases at times. But apart from thinking seriously of moral fault of United States Steel, or Ford Motor, or General Electric, or Standard Oil of New Jersey, to reckon the cost of injuries incidental to the operation of the enterprise is a question of economics rather than of ethics. It is not a matter of the moral obligation of an individual, but of the regulation of economic operations, to accord with our ideals of the legal order, if you will, but not to accord with an ideal of relations of individual with individual in everyday individual relations.

"Spreading the loss" as a theory of liability to repair injuries without fault in the course of undertakings under the control of organizations which are conducted for the profit of the organizations had no analogy in the older law of obligations ex delicto or of torts upon which to go. Careless handling of a loaded musket could go on the analogy of willful handling of the musket. Both involved fault - falling short of one's moral duty. But when we come to injuries to workers in industrial plants, going on the principle of fault as the basis of liability made it seem as if we were applying the method of the pickpocket who attended the charity sermon and was so moved by the preacher's eloquence that he picked the pockets of everyone in reach and put the contents in the plate.

Economics, as well as ethics, must come into the reckoning of our positive law. A universal ideal may take account of each. A positive natural law that goes on a postulated ideal of responsibility only for moral shortcoming has balked at the problem of a basis of liability for injuries in industry.

Let us look again at some of the analogies which have given shape to decisive institutions and doctrines and precepts of the law of yesterday with which we seek to operate the legal order today: the analogy of the street fight in Rome of 450 B.C.; the analogy of the hostage substituted as debtor; the analogy of the defaulting debtor chained up or tied up (we still say he is bound) and so the bound wrongdoer, the bound debtor for loaned coined money, and the bound defaulting borrower of a horse; the analogy of the trial of a formally framed single issue. Reasoning shaped to these analogies and giving shape to legal doctrines and precepts has been at work both as an agency of legal development and as an agency of holding back the inevitable forward movement of the law to meet the demands of advancing civilization.

A serious item in the persistence of fault liability, the insistence of a moral duty of one man toward another as the sole basis of liability, is the abuse of the term "privity." It has been assumed that there must of necessity be some relation of one party to the other to which to attach a duty to make reparation for injury. A moral duty could be brought into the ideal picture as an 
incident of some relation. Hence the old fellow-servant rule. There was no relation between fellow employee and fellow employee as to the conduct of the employment. So there was no default of moral duty of one to the other for which liability could be justly imposed upon the employer. Again take the leading case of McPherson v. Buick Motor Co. ${ }^{12}$ Plaintiff bought a car from a retail dealer who had bought it from the manufacturer, who, in making the car, used a wheel made by another manufacturer. The wheel was made of defective wood and its spokes crumbled, causing injury to the plaintiff. Here there was a relation of buyer and seller between plaintiff and the retail dealer but none between plaintiff and the maker of the car, who could have detected the defective wheel and by putting the car on the market imposed an unreasonable risk of injury upon the public and so upon the plaintiff who bought the car. For seventy years the common law courts had been denying liability in such cases for want of privity. Today the threat to the general security from putting on the market a car with a defective wheel, or a bottle of coca cola with a flaw which may result in its bursting in the hands of a purchaser, has compelled the courts to give up the idea of privity. Without any moral fault, the business of manufacture may create a risk imposed upon those who buy which justifies imposing a duty of repairing injuries to be met as part of the cost of manufacture.

Logical quest of a universal may help here. But a plausible assumption of positive natural law long retarded our finding it.

Logic is a chief instrument of natural law. But logic is limited by the limits of its starting points. The street fight in Rome of the regal period could not by logical development of the idea do the work of a theory of legal procedure for today. Logical development of a conception of a morally blameworthy act by one individual which results in injury to another individual could not give us a universal theory of liability that would meet requiring a great economic enterprise to bear the human no less than material wear and tear involved in its operation.

Although they purported to expound natural law, the jurists of the lawof-nature school, which ruled in the science of law from the seventeenth to well into the nineteenth century, were inhibited by the limits of assumed eternal unchallengeable starting points.

When, in 1899, I first essayed to teach jurisprudence, the authoritative text on natural law was Ahrens' Cours de droit naturel - a book which went through twenty-four editions in seven languages. In this book, an exception-

12. 217 N.Y. 382 , 111 N.E. 1050 (1916). 
ally clear and logically developed exposition of nineteenth-century systems of law, I read:

Every obligation is founded upon a reason or a cause, which itself resides in a permissible and juridically pursued end. . . . In obligations arising from delicts the reason consists in the necessary reparation of the damage caused by fault or by fraud. ${ }^{13}$

I am afraid I taught this as a fundamental principle of the law of torts as late as 1904.

Here we have a striking illustration of the extent to which reasoning takes the form of fitting a theory to an analogy. Historically, the law of liability to repair injuries did start with assault and battery. Historically, we did see that there was a wide idea of fault to which assault and fraud and negligence could be attributed. The inadequacy of fault as an idea back of all liability has come hard. But in limiting liability as we did were we looking at liability sub specie aeternitatis or were we looking at eternity sub specie juris civilis?

A recent writer speaks of "some of the features of social insurance behind the façade of legal rules inherited from the heyday of individualism and laissez faire." 14 Such phenomena of an industrial economy as occupational diseases have reinforced the movement away from the dogma of necessary sequences of fault and duty of reparation. Indeed at least five cases of liability without fault have become recognized in the law reports apart from such legislation as Workmen's Compensation Acts, the Federal Employers' Liability Act, the Jones Act, the Boiler Inspection Act, and the Safety Appliance Acts, and the aerial navigation laws in at least twenty-one states. An older example was furnished by the Dram Shop Acts in the nineteenth century. The established common law liabilities without fault are now: (1) bringing upon land dangerous quantities of substances not naturally there, (2) damage by trespassing domestic animals turned at large by wrongdoers without fault of their owner who is held liable, (3) keeping dangerous animals, (4) use of high explosives, (5) use of poison sprays for proper purposes and with all due care. It cannot be that this steady movement of American law away from liability only as necessary consequence of fault is an evidence of giving up of reason by a morally decadent world. Is it not significant that the courts today are giving lib-

13. Ahrens, 2 Cours de droit naturel 76 (8th ed., 1892).

14. Fleming James, Indemnity, Subrogation, and Contribution and the Efficient Distribution of Accident Losses, 21 NACCA [National Association of Claimants' Compensation Attorneys] LAW Journal 360, 362 (1958). Professor James mentions the dilution of the fault requirement by expansion of res ipsa loquitur, negligence as matter of law, and the increasing use of warranty in products liability cases; the jury system; enlarged notions of vicarious liability, especially in the automobile field; and the institution of liability insurance. Id. at $361,362$. 
eral construction to such legislation as the Federal Employers' Liability Act, which in the last century would have been narrowly interpreted as in derogation of the common law?

Working out of a general theory of imposing reparation of injuries incident to industrial undertakings upon the enterprises of which they are incidents has been achieved in spite of the supposedly universal dictate of reason that liability was a necessary result of fault and fault the necessary basis of liability. Perhaps that is a principle not of natural natural law but of positive natural law. At any rate, it was an application of reason to the man-to-man relation of an agricultural society. Today we are having to apply reason to relations of individual men employing instrumentalities potentially dangerous to themselves in operations controlled by others in an industrial society. Do we not put too heavy a burden upon reason in expecting it to give us a complete and perfect system of justice, formulated in detailed precepts, good for all times and places and peoples to come? May we not turn to experience also? 